Vol. 24, No. 2, pp. 203 212, 2021.

\title{
Mechanisms for Thermoelectric Power Factor Enhancement in Composite Thermoelectric Materials
}

\author{
Dongwook Lee ${ }^{1 \dagger}$ \\ ${ }^{1}$ Department of Materials Science and Engineering, Hongik University, 94 Wausan-ro, Sangsu-dong, Mapo-gu, Seoul 04066, \\ Republic of Korea
}

\section{복합 열전 소재에서 출력인자 증강 메커니즘들}

\author{
이동욱 ${ }^{\dagger}$ \\ 1홍익대학교 신소재공학과 \\ Received April 10 2021; Revised May 12 2021; Accepted May 132021
}

\begin{abstract}
s
Thermoelectrics can convert low-grade heat into electricity is essential to meet the increasing demand for renewable energy systems. However, their heat-to-electricity conversion efficiency is governed by a material factor, thermoelectric figure of merit (ZT). ZT is limited by the tradeoff between thermal conductivity, electrical conductivity, and Seebeck coefficient, all of which are coupled. Taking thermoelectric material system into nanoscale composites is a common strategy to raise or tune the material-related term ZT. ZT is determined by thermal conductivity and power factor, which is product of square of Seebeck coefficient and electrical conductivity. Nanoscale composites inherently possess phonon scattering centers that can suppress thermal conductivity. Besides, two main power factor enhancement mechanisms were identified for nanoscale composite systems; (i) modulation doping and (ii) energy-dependent charge carrier scattering. In this paper, principles and reported examples of those two power factor improvement mechanisms will be outlined and summarized.
\end{abstract}

Keywords: Thermoelectrics, Composite, Modulation doping, Energy-dependent charge carrier scattering

†Corresponding Author: dongwook@hongik.ac.kr 


\section{1. 서론}

전 세계의 에너지 수요가 증가하고 재생 불가능한 화 석 연료의 양이 감소함에 따라 지속 가능한 재생 가능 에너지원에 대한 필요성이 분명해졌다. 이러한 에너지 문제에 대한 해결책은 낭비되는 에너지의 양을 줄임으 로써 실현될 수 있다. 전세계적으로 생산되는 에너지 중 $41 \%$ 만이 유용성 있는 에너지로 사용되며 나머지 57.5 $\%$ 는 최종적으로 폐열의 형태로 낭비된다. 가장 풍부한 미활용 에너지인 폐열을 유용한 전기 에너지로 재생산 한다면 미래에 에너지 수급이 개선될 수 있다.

열전은 부피를 작게 만들 수 있고, 따라서 설치 공간 의 제약을 덜 받는 폐열 회수 기술이다. 열전의 성능을 나타내는 가장 대표적인 척도는 열 변환 효율이고, 이로 부터 다른 열전 성능에 대한 척도가 유도된다.

$$
\eta=\frac{\mathrm{T}_{\mathrm{H}}-\mathrm{T}_{\mathrm{C}}}{\mathrm{T}_{\mathrm{H}}} \frac{\sqrt{\mathrm{ZT}+1}-1}{\sqrt{\mathrm{ZT}+1}+\frac{\mathrm{T}_{\mathrm{C}}}{\mathrm{T}_{\mathrm{H}}}}
$$

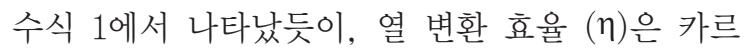
노 효율 $\left(\frac{\mathrm{T}_{\mathrm{H}}-\mathrm{T}_{\mathrm{C}}}{\mathrm{T}_{\mathrm{H}}}\right)$ 과 재료에 의한 효율 $\left(\frac{\sqrt{\mathrm{ZT}+1}-1}{\sqrt{\mathrm{ZT}+1}+\frac{\mathrm{T}_{\mathrm{C}}}{\mathrm{T}_{\mathrm{H}}}}\right)$ 이라 는 두 가지 구성 요소의 곱이다. 카르노 효율 (Carnot efficiency)은 고온 부 $\left(\mathrm{T}_{\mathrm{H}}\right)$ 와 저온 부 $\left(\mathrm{T}_{\mathrm{C}}\right)$ 온도를 사용 하는 열역학 제 2 법칙에 의해 정의되는 효율이고, 재료
에 의한 열 변환 효율은 장치에 사용 된 열전 재료의 특 성에 따라 결정된다. 재료에 의한 효율 $\left(\frac{\sqrt{\mathrm{ZT}+1}-1}{\sqrt{\mathrm{ZT}+1}+\frac{\mathrm{T}_{\mathrm{C}}}{\mathrm{T}_{\mathrm{H}}}}\right)$ 에 는 무차원 성능 지수 (ZT, thermoelectric figure of merit)로 알려진 항이 있고, 이는 재료의 전기 전도도 ( $\sigma$, electrical conductivity), 제벡 계수 (S, Seebeck coefficient), 열 전도도 ( $\kappa$, thermal conductivity) 및 평균 온도 (T)에 의해 결정된다 (수식 2).

$$
\mathrm{ZT}=\frac{\sigma \mathrm{S}^{2}}{\kappa} \mathrm{T}
$$

열전 장치의 효율을 극대화하려면 ZT를 극대화해야 한다. 따라서 열전 재료에 대한 연구의 대부분은 ZT를 높이는 것을 목표로 하고 있다. 그러나 ZT를 높이기 위 해서는 한 재료 내에서 재료의 전기 전도도 $(\sigma)$, 제벡 계 수 $(\mathrm{S})$, 열 전도도 $(\kappa)$ 의 의미와 그들 사이의 대립 관계 (tradeoff)를 이해해야 한다.

열전 재료는 일반적으로 높은 농도의 전하 캐리어 (정 공 또는 전자, $\mathrm{h}^{+}$또는 $\mathrm{e}^{-}$)를 가진 좁은 밴드 갭 반도체 (narrow band gap semiconductors)이다. 열전 재료가 온도 구배를 받으면 캐리어가 재료의 차가운 부분으로 이동하는 경향이 있다 (Fig 1). 온도 구배에서 캐리어 농 도의 이러한 불균형은 운동 에너지가 낮은 저온의 캐리 어보다 고온의 캐리어가 더 큰 확산 계수 (diffusivity)를

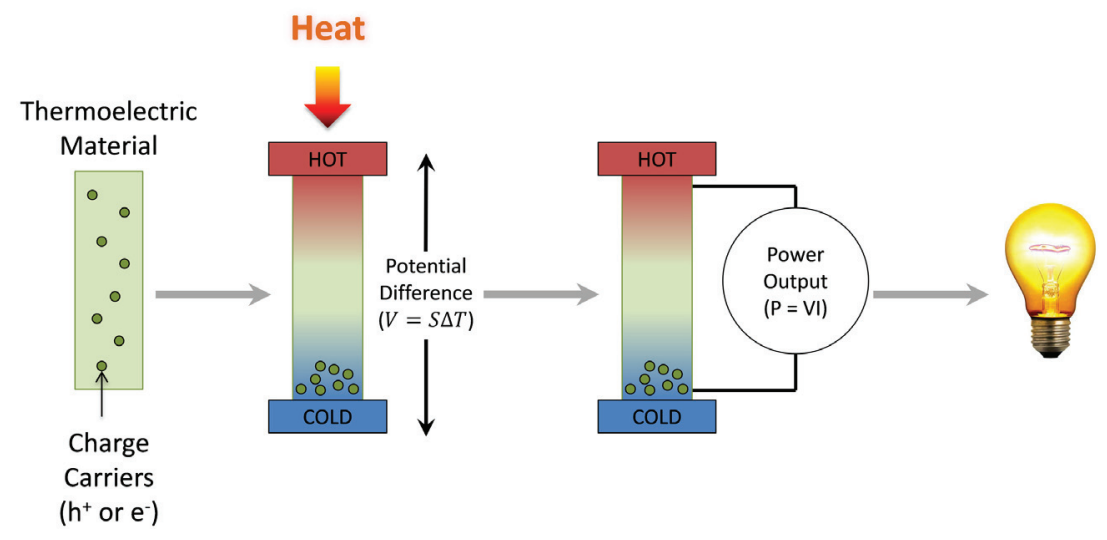

Fig 1. 열전 효과는 금속이나 반도체와 같은 전도성 재료에서 발생한다. 온도 구배가 주어졌을 때, 재료 내부의 전하 캐리어는 온도가 낮은 쪽으로 편중된다 (polarized). 이는 재료 내의 온도 차를 따라 전위 차, 즉 전압을 생성하고, 이는 전기적 일로 변환될 수 있다. 


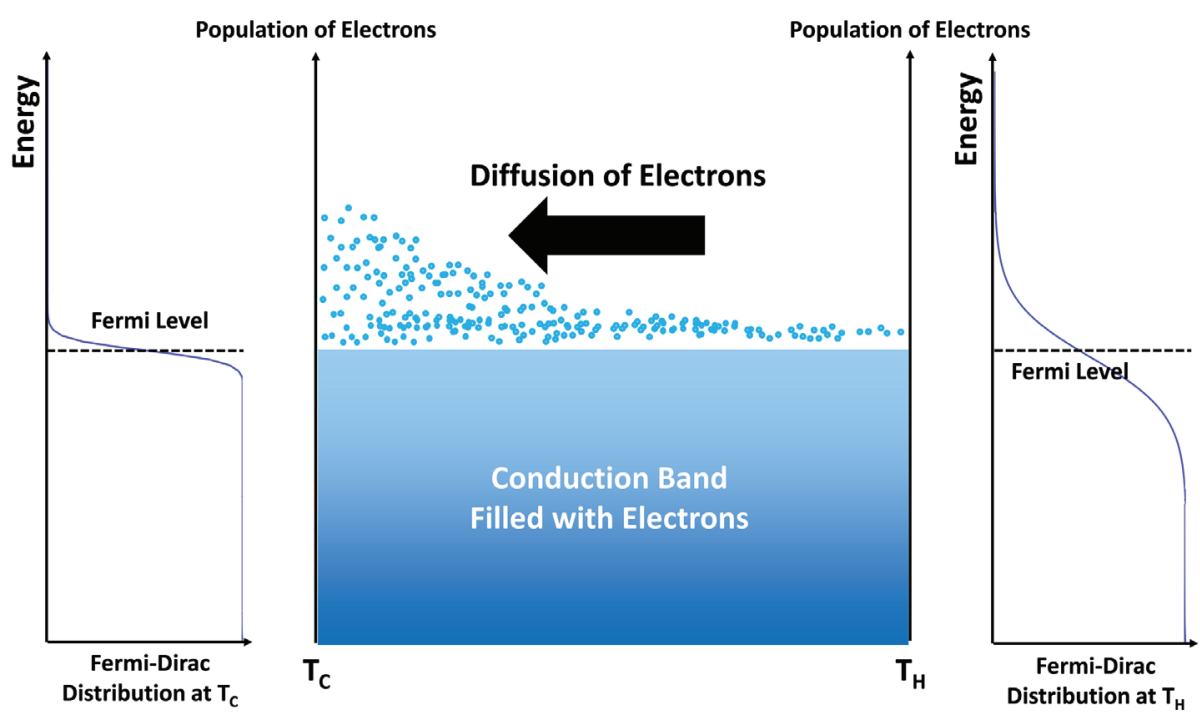

Fig 2. 열전 재료의 일종인 금속에서의 제벡 효과를 미시적인 관점에서 나타낸다. 고온 $\left(T_{H}\right)$ 쪽에 있는 자유 전자는 저온 쪽에 있는 자유 전 자에 비해 평균적으로 더 높은 운동 에너지, 즉 평균적으로 더 큰 속도를 가진다. 통계적으로, 전자는 차가운 쪽으로 편중되고, 전자의 공간적 편중은 전압을 일으킨다. 같은 현상이 비단 금속 뿐 아니라 반도체에서도 일어나고, 그 반도체는 현재까지 개발된 대부분의 열전 소재를 포함한다.

가진 데서 비롯된다 (Fig 2). 열전 재료의 저온부에서 캐 리어의 “축적"은 재료의 부분 별로 전압 차이를 생성한 다. 물질의 제벡 계수 $(\mathrm{S})$ 는 수식 3 에서 볼 수 있듯이 주 어진 온도 구배 $(\Delta \mathrm{T})$ 에 의해 생성된 전압 $(\Delta \mathrm{V})$ 의 크기를 정량화한다. 그런 다음 재료가 외부 부하에 연결되어 전 류가 흐르면서 전력 출력을 생성한다. 열전 재료는 전기 에너지 저장 능력을 가지고 있지 않기 때문에 수확된 전 력은 생산된 동시에 소비되어야만 하고, 그렇지 않다면 낭비될 뿐이다. 또한 수식 3 에서 나타났듯이, 캐리어 농 도가 낮을수록 제벡 계수는 상승한다는 점에 주목할 필 요가 있다 (반도체 열전 재료의 포물선형 밴드를 가정 $)^{2}$.

$$
\mathrm{S}=\frac{\Delta \mathrm{V}}{\Delta \mathrm{T}} \propto \mathrm{n}^{-\frac{2}{3}}
$$

재료의 전기 전도도 $(\sigma)$ 는 전기를 얼마나 잘 전도하는 지 정량화하고, 캐리어 농도 $(\mathrm{n})$, 이동도 $(\mu)$ 및 기본 전 하 상수 (e)의 곱이다 (수식 4), 캐리어 농도는 재료의 전도대 (conduction band)에 있는 전자 또는 가전자대 (valence band)에 있는 정공의 농도이다. 이동도는 캐
리어가 재료를 통해 얼마나 쉽게 이동할 수 있는지를 나 타낸다. 기본 전하 상수 (e)는 단일 전자 $\left(1.6 \times 10^{-19} \mathrm{C}\right)$ 가 운반하는 전하로 정의된다.

$$
\sigma=n e \mu \quad \text { 수식 } 4
$$

재료의 총 열 전도도 (๙)는 열 전도율을 정량화하고, 이는 격자 열 전도도 $\left(\kappa_{\mathrm{L}}\right)$ 와 전자 열 전도도 $\left(\kappa_{\mathrm{e}}\right)$ 기여의 합이다 (수식 5). 격자 열 전도도는 재료를 통해 전달되 는 격자 진동에서 비롯되고, 이를 음향양자 (phonon) 라고도 일컫는다. 전자 열 전도도는 전하 캐리어와 재료 내 원자 간의 충돌에서 비롯되므로, Lorentz 수 (L)와 전기 전도도 $(\sigma)$ 의 곱에 비례한다 (수식 6).

$$
\begin{array}{ll}
\kappa=\kappa_{\mathrm{e}}+\kappa_{\mathrm{L}} & \text { 수식 } 5 \\
\kappa_{\mathrm{e}}=\sigma \mathrm{LT} & \text { 수식 } 6
\end{array}
$$

수식 2에서 알 수 있듯이, 높은 ZT를 달성하여 높은 열 변환 효율을 구현하려면 전기 전도도, 제벡 계수의 증가 및 열 전도도의 감소가 바람직하다. 그러나 높은 $\mathrm{ZT}$ 를 달성하는 것은 이들 3 가지 계수가 서로 관련되어 

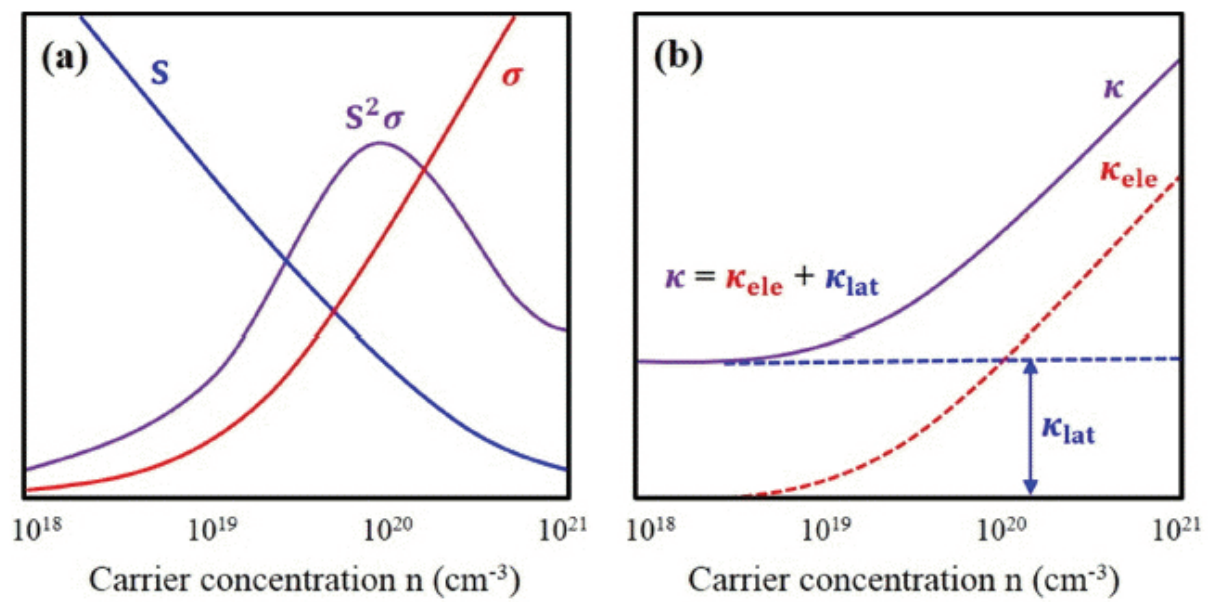

Fig 3. 전하 캐리어 농도를 통한 무차원 성능 지수 (ZT)의 최적화. 한 가지 열전 재료 내에서 ZT의 최대화는 열 전도도 (k), 제벡 계수 (S), 그 리고 전기 전도도 사이의 대립 관계 (tradeoff) 를 조율해야 성취될 수 있다. Figure from Design and Preparation of High-Performance Bulk Thermoelectric Materials with Defect Structures and used with permission from Korean Ceramic Society ${ }^{18}$.

있기 때문에 간단하지 않다.

Fig 3은 열전 물질 내부의 전하 캐리어 농도의 함수로 서 제벡 계수, 전기 및 열 전도도를 보여준다. 전기 전 도도는 캐리어 밀도가 증가함에 따라 증가하는 반면 제 벡 계수는 캐리어 농도가 증가함에 따라 감소한다. 제벡 계수와 전기 전도도의 상반된 추세로 인해, 특정 캐리어 농도에서 출력인자의 최댓값이 존재하게 된다. 또한 캐 리어 밀도가 증가함에 따라 열 전도도도 증가하는데, 이 는 열 전도도에 대한 전자 기여 분이 더 커지기 때문이 다. 이 분석을 통해 ZT는 특정 캐리어 농도에서 최대 값 도 가짐을 추론할 수 있다.

ZT의 추가적 개선을 위해 여러 연구가 시행되었고, 이 전략은 거칠게 2 가지 흐름으로 나눌 수 있다. 1 번째 는 수식 2 의 분모인 열 전도도를 낮추는 것이고, 2 번째 는 수식 2의 분자에 해당하는 출력인자 (power factor) 을 최대화하는 것이다. 열전 소재를 복합 소재로 만드는 전략은 음향양자가 산란되는 장소를 대량으로 생성하여 열 전도도를 낮추는 동시에, 출력인자을 증강시킬 가능 성이 있다는 점에서 많이 연구되었다 ${ }^{3-13}$. 본 논문에서는 복합 소재에서 출력인자을 증가시키는 메커니즘들에 대 해 집중적으로 탐구하고, 이 메커니즘을 실제로 구현하 기 위해 갖추어야 하는 조건과 원리, 구현된 예제에 대
해 요약할 것이다.

\section{변조 도핑 (modulation doping)}

변조 도핑은 전하 캐리어를 많이 가진 재료 $\mathrm{A}$ 로부터, 전하 캐리어가 적은 인접 재료 $\mathrm{B}$ 로 전하 캐리어가 확산 되는 현상을 일컫는다. (Fig 4 (a)). 이 상황에서 재료 B 는 불순물인 도판트 없이도 전하 캐리어의 수량이 늘어 나는 효과를 얻기 때문에 도핑으로 분류된다. 순서 상으 로는 (i) 도핑 된 반도체 층에서 전하 캐리어의 생성 및 (ii) 더 높은 이동성을 갖는 접촉 도핑 된 층으로의 전하 캐리어의 일부 이동의 두 가지 프로세스로 구성되고, 따 라서 전하 캐리어가 재료 $\mathrm{A}$ 에서 재료 $\mathrm{B}$ 로 '넘치는' 현상 이라고도 서술할 수 있다. 도핑되지 않은 층에서 더 높 은 전하 캐리어 이동도가 이루어지는 이유는 도펀트 원 자에 의한 캐리어 산란이 적기 때문이다. 이 메커니즘은 전하 캐리어를 추가로 생성하지 않기 때문에, 전하 캐리 어의 전체 인구는 동일하게 유지된다. 그러나 도핑되지 않은 층 (재료 B)의 일부 전하 캐리어가 이제 더 높은 이 동도를 갖기 때문에 전기 전도도가 증가한다. 이 원리는 $\mathrm{GaAs} / \mathrm{Al}_{\mathrm{x}} \mathrm{Ga}_{1-\mathrm{x}} \mathrm{As}$ 초격자에서 처음으로 입증되었다 ${ }^{14}$. 이 개념의 첫 번째 적용은 전하 캐리어의 높은 이동 
(a)

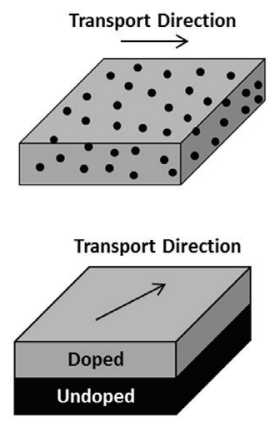

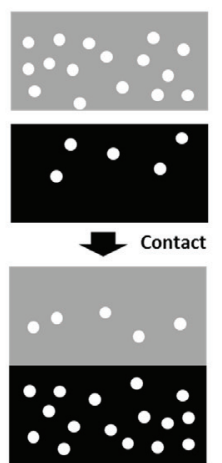

(b)

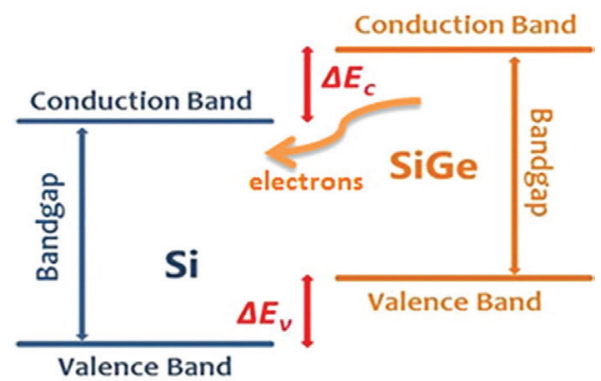

\section{3-D Modulation-doping}

Fig 4. 나노 스케일 복합 재료에서 변조 도핑 메커니즘. (a) 변조 도핑은 전하 캐리어의 이동 방향이 재료 간 계면과 평행일 때 열전 성능을 향상시키는 원리가 될 수 있다. 회색은 도핑되었으나 전하 이동도가 낮은 재료를 나타내고, 검은색은 도핑되지 않았으나 전하 이동 도는 더 큰 재료를 의미한다. 흰 점으로 표시한 전하 캐리어가 도핑이 많이 된 재료로부터 농도 구배 때문에 확산되는 과정을 보여 준다. (b) 변조 도핑은 화학적으로 도핑된 재료로부터 더 높은 이동도를 가진 인접 재료로 전하 캐리어가 “흘러 넘치는" 현상이다. 도 핑 농도의 차이 이외에도, 전하 캐리어의 흘러 넘침이 열역학적으로 안정한 현상이 될 수 있도록 계면에서 밴드 불연속 (band offset) 이 구현되어야만 비로소 변조 도핑이 효과적으로 일어날 수 있다. 다른 말로, 이는 밴드 불연속의 크기와 방향에 따라, 얼마나 많은 분율의 전하 캐리어가 흘러 넘쳐서 이주할 수 있는지 결정된다. 이 경우, 고농도로 도핑 된 $\mathrm{Si}_{x} \mathrm{Ge}_{1-x}$ 나노 입자에서 생성된 전자는 인 접한 도핑되지 않은 Si 매트릭스로 흘러넘친다. 이는 전하 캐리어의 농도 구배와 밴드 불연속이 모두 이 방향으로의 전하 캐리어 확 산을 지지하기 때문이다. Figure (a) from Quantitative analyses of enhanced thermoelectric properties of modulation-doped PEDOT:PSS/undoped Si (001) nanoscale heterostructures ${ }^{15}$. Reproduced by permission of the Royal Society of Chemistry. Figure (b) from Enhancement of thermoelectric properties by modulation-doping in silicon germanium alloy nanocomposites and used with permission from the American Chemical Society ${ }^{6}$.

도가 성능과 직접적으로 연결된 HEMT (high electron mobility transistor)였다 ${ }^{14}$.

변조 도핑이 활발하게 실현되어 많은 양의 전하 캐리 어가 재료 $\mathrm{A}$ 에서 재료 $\mathrm{B}$ 로 '많이 넘치기' 위해서는 전하 캐리어의 이동이 열역학적으로 내리막 (자발적인 발열 반응)이어야 하고, 이는 재료 $\mathrm{A}$ 와 재료 $\mathrm{B}$ 의 계면에서의 밴드 불연속 (band offset)으로 결정된다. 밴드 불연속 은 서로 다른 두 재료의 경계면에서, 전도대 또는 가전 자대가 보이는 불연속 에너지의 크기이다. 밴드 불연속 이 열역학적으로 오르막이라면 (비자발적 흡열반응) 재 료 $\mathrm{A}$ 에서 인접한 도핑되지 않은 반도체 재료 $\mathrm{B}$ 로의 확 산이 크게 억제된다. 반대로 전하 캐리어의 재분배가 열 역학적으로 유리할 때 (내리막), 대부분의 전하 캐리어 는 인접 재료 $\mathrm{B}$ 로의 재배치를 선호한다 ${ }^{6,7,15,16}$.

Fig 4 (b)는 n형으로 많이 도핑된 $\mathrm{Si}_{\mathrm{x}} \mathrm{Ge}_{1-\mathrm{x}}$ 나노 입자 를 함유하는 도핑되지 않은 $\mathrm{Si}$ 매트릭스에서 일어나는 변조 도핑 과정을 보여준다. 이 경우, 전하 캐리어를 제 공하는 재료 $\mathrm{A}$ (많이 도핑된 $\mathrm{n}$ 형 $\mathrm{Si}_{\mathrm{x}} \mathrm{Ge}_{1-\mathrm{x}}$ 나노 입자)의
전도대는 도핑되지 않은 $\mathrm{Si}$ 의 전도대보다 에너지적으로 높게 위치한다. 이는 전하 캐리어의 확산이 열역학적으 로 유리하도록 밴드가 정렬하도록 재료를 선택했기 때 문이다. 따라서 전하 캐리어의 재배열이 열역학적 내리 막 반응 (발열반응)임을 의미하고, 자발적으로 변조 도 핑이 발생함을 의미한다.

이 경우, 전하 캐리어를 제공하는 재료 $\mathrm{A}$ 에 해당하는 $\mathrm{Si}_{\mathrm{x}} \mathrm{Ge}_{1-\mathrm{x}}$ 나노 입자는 일반적으로 전자의 산란 중심으로 간주된다 ${ }^{6,7}$. 이 효과가 우세하다면 변조 도핑이 일어났 음에도 불구하고 전기 전도도의 향상은 일어나지 않을 수 있다. 인용된 해당 논문에서는 ${ }^{6,7} \mathrm{Si}_{\mathrm{x}} \mathrm{Ge}_{1-\mathrm{x}}$ 나노 입자 의 크기가 $(\sim 20 \mathrm{~nm})$ 전자의 평균 자유 경로 $(1 \mathrm{~nm}-$ $20 \mathrm{~nm}$ )보다 크기 때문에 전기 전도도의 향상이 가능하 였다. 즉, 해당 복합 열전 재료에서 대부분의 전자는 나 노 입자에 의해 산란되기보다는 도핑되지 않은 $\mathrm{Si}$ 매트 릭스 그 자체로 인해 산란된다. 변조 도핑을 일으키는 변조 도판트가 나노 입자일 때, 나노 입자의 크기는 전 하 캐리어의 평균 자유 경로보다 작아야 한다는 교훈이 


\section{특 집 ․․ 이동욱}
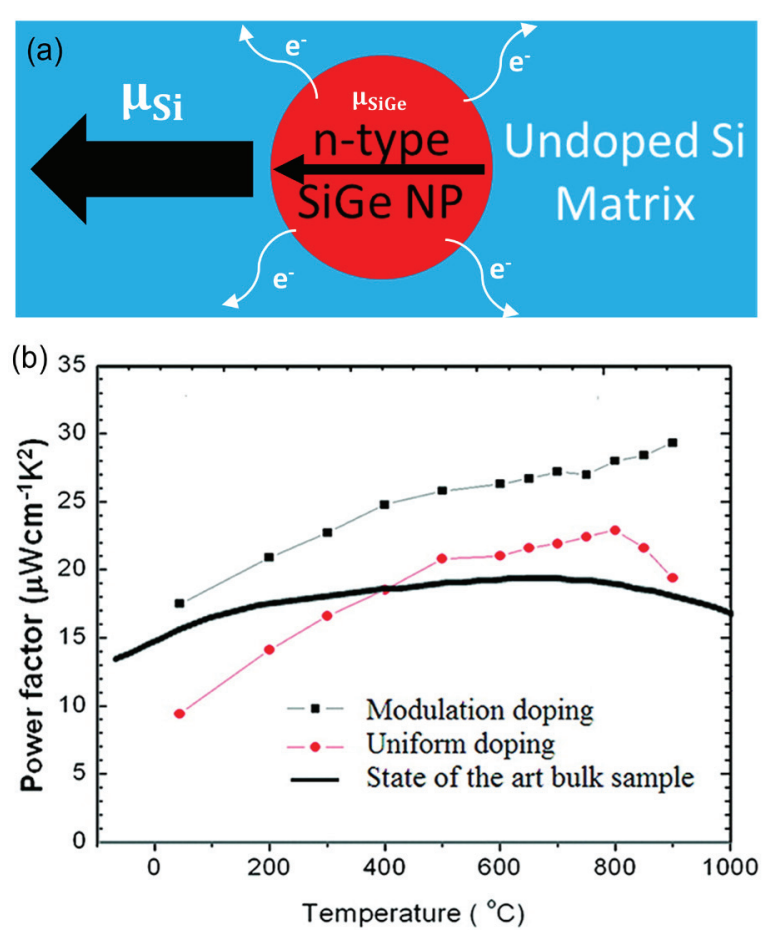

Fig 5. (a) 도핑되지 않은 $\mathrm{Si}$ 매트릭스와 $\mathrm{n}$ 형 $\mathrm{Si}_{x} \mathrm{Ge}_{1-\mathrm{x}}$ 나노 입자의 복합 재료에서 변조 도핑. $\mathrm{n}$ 형 도핑된 $\mathrm{Si}_{x} \mathrm{Ge}_{1-x}$ 나노 입자로 부터 흘러넘친 전자는 높은 이동도를 가진 Si 매트릭스를 통 해 더 빠르게 이동하여 전기 전도도를 개선한다. (b) 해당 복 합 재료는 균일하게 도핑된 Si에 비해서 출력인자이 개선되 었음을 볼 수 있고, 이러한 향상은 주로 제벡 계수의 손해 없 이 전기 전도도가 증가했기 때문으로 분석된다. Figure (b) from Power factor enhancement by modulation doping in bulk nanocomposites and used with permission from the American Chemical Society?

도출된다. 열전 성능에 있어서, 변조 도핑의 결과로 제 벡 계수를 희생하지 않고도 전기 전도도가 향상되었고, 이는 출력인자의 증강으로 이어졌다 (Fig 5 (b)). 이 전 략의 또 다른 장점은 $\mathrm{Si}_{\mathrm{x}} \mathrm{Ge}_{1-\mathrm{x}}$ 나노 입자가 음향양자 또 한 산란시키고, 이로 인해 열전도를 억제한다는 점이다 6,7 . 음향양자의 평균 자유 경로 (수 $\mu \mathrm{m}$ 가량)가 전자의 그것에 비해 훨씬 길기 때문에, 수십 $\mathrm{nm}$ 마다 산란 중심 인 나노 입자가 분포하는 상황은 전자에 비해 음향양자 의 산란이 훨씬 심각해짐을 의미한다. ${ }^{4,5}$

\section{전하 캐리어 산란 (energy-dependent charge carrier scattering)}

이 메커니즘은 서로 다른 두 재료 사이의 계면에서 발 생하는 밴드 불연속 (band offset)이 전하 캐리어의 에 너지 장벽으로 작용할 때, 에너지가 낮은 캐리어가 에너 지가 높은 캐리어에 비해 더 높은 확률로 산란됨을 이용 한다. 그를 통해 전하 캐리어의 이동도와 전기 전도도를 일부 희생함으로써, 제벡 계수를 키우고 종국에는 출력 인자을 증강시키는 전략이다. 열역학적인 관점에서 제 벡 계수는 전하 캐리어 1개가 수송하는 평균 엔트로피이 다 ${ }^{2}$. 따라서 이 전략은 전하 캐리어 1 개 당 수송하는 평 균 엔트로피의 크기를 높게 만들어, 제벡 계수를 올리 는 방식이다. 재료 $\mathrm{A}$ 와 재료 $\mathrm{B}$ 가 일정한 두께를 가지고 반복적으로 증착되어 있는 초격자 (superlattice) ${ }^{13}$ 또는 매트릭스에 묻힌 나노 입자 ${ }^{10}$, ${ }^{11}$ 는 이 전하 캐리어 산란 메커니즘을 일으키기 위해 선호되는 복합 소재 구성 방 식이다. 이를 통해 전하 캐리어의 산란이 일어나는 계면 에 의한 효과를 의도적으로 늘이거나 줄이는 통제가 가 능하기 때문이다 (Fig 6 (a)).

Fig 6 (b)는 이러한 복합 열전 재료에 온도 구배가 가 해졌을 때의 전하 캐리어의 에너지를 보여준다. 온도 구 배 때문에 복합 재료 내의 전자는 위치 별로 다른 평균 운동 에너지를 가지게 됨이 나타나있다. 또한, 양자 우 물 (quantum well)이 가정되어 있는데, 이는 초격자를 이루는 복합 재료 중 1 개의 두께가 양자 구속 (quantum confinement effect) 효과를 일으킬 정도로 얇은 상황 을 상정하기 때문이다. 전자가 복합 소재를 구성하는 재 료 $\mathrm{A}$ 와 재료 $\mathrm{B}$ 의 계면을 건너서 이동하면, 로 표현되는 장벽보다 작은 에너지를 가진 전자들은 더 이상 나아갈 수 없다. 오로지 장벽 높이보다 더 높은 운동 에너지를 가진 전자들 $\left(\mathrm{E}>\mathrm{E}_{\mathrm{b}}\right)$ 만이 계속 이동할 수 있다. 이 경우 장벽을 뚫는 터널링 효과는 무시된다.

이를 시각적으로 나타낸 것이 Fig 6 (c)이고, 복합 재 료 내의 전자 중 얼만큼이 계면의 에너지 장벽을 통과하 는지를 보여준다. 복합 재료 내 전체 전자의 에너지는 운동량 공간 ( $\mathrm{k}$ 공간)에 표시되었다. 등방성 자유 전자 가 가정되기 때문에 운동 에너지는 운동량 공간에서 구 형의 분포를 띠고, 이는 금속 (페르미 가스)의 전형적인 특성을 반영한다. 계면에서의 에너지 장벽을 뚫고 전달 
(a)

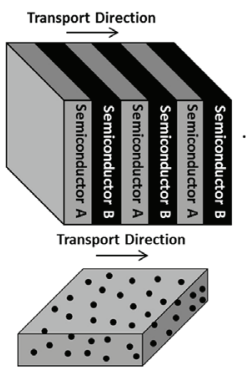

(d)

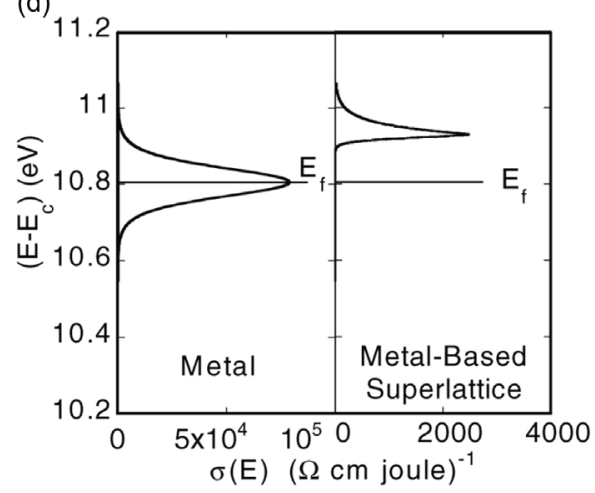

(b) Transport
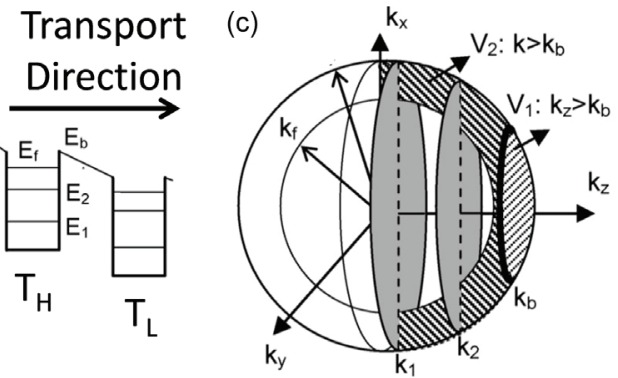

(e)

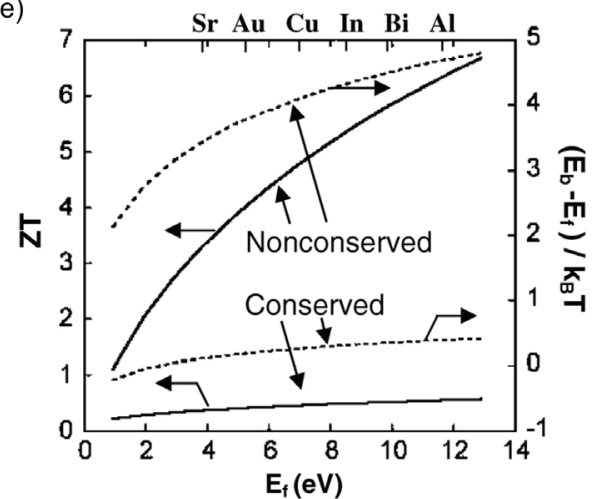

Fig 6. (a) 초격자 (superlattice)를 포함한 나노스케일 복합 재료에서 계면 장벽 에너지에 따른 전하 캐리어 산란 메커니즘. 이 메커니즘은 나노 입자들과 그를 감싼 매트릭스, 혹은 초격자에서 전기 전도도를 희생하는 댓가로 제벡 계수를 향상시킬 수 있다. 이 메커니즘을 일으키려면 전하 캐리어와 열의 전달은 재료 사이의 “계면을 뜷는 방향”으로 일어나야 한다. 회색과 검은색은 각각 전도성 재료 $A$ 와 다른 종류의 전도성 재료 $\mathrm{B}$ 를 나타내고, 흰 점은 전하 캐리어를 모사한다. 계면에서 일어나는 전하 캐리어의 산란이 묘사되어 있다. (b) 2 가지 재료가 초격자의 형태로 복합 재료를 형성할 때 가전자대 (conduction band). 2가지 재료 중 한 가지는 얇은 두께로 인해 양자 구속 효과 (quantum confinement effect)를 가진다고 상정되어, 양자 우물 (quantum well)의 형태로 표현되었다. 각 우물의 장

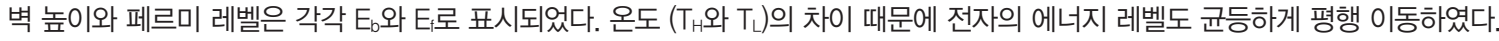
(c) 복합 재료 내 모든 전자의 운동 에너지 분포는 운동량 공간 ( $\mathrm{k}$ 공간)으로 표시될 수 있다. 계면 장벽의 높이 $\mathrm{E}_{\mathrm{b}}$ 보다 더 큰 운동 에 너지를 가진 전자만이 계면을 “뛰어넘어" 전달될 수 있고 ( $\vee_{1}$ 과 $\vee_{2}$ 에 해당), 그렇지 않으면 산란된다. (d) 복합 재료 내 계면에서 에너 지 장벽이 있을 때의 $\sigma(\mathrm{E})$ 함수. $\sigma(\mathrm{E})$ 함수는 해당 에너지 $\mathrm{E}$ 를 가진 전자 분율로 인한 전기 전도도이고, 페르미 레벨에서의 $\sigma(\mathrm{E})$ 함수 의 기울기가 제벡 계수에 비례한다. (e) 장벽 에너지에 의한 전하 캐리어 산란 메커니즘 시 예상되는 ZT의 개선 정도. Figure (a) from Quantitative analyses of enhanced thermoelectric properties of modulation-doped PEDOT:PSS/undoped Si (001) nanoscale heterostructures ${ }^{15}$. Reproduced by permission of the Royal Society of Chemistry. Figure (b) - (e) from Improved thermoelectric power factor in metal-based superlattices and used with permission from the American Physical Society ${ }^{13}$.

될 수 있는 '여과'의 기준 운동 에너지는 다음 공식에 의 해 운동량과 관련된다.

$$
\mathrm{E}=\frac{\hbar^{2} \mathrm{k}^{2}}{2 \mathrm{~m}_{\mathrm{e}}^{*}}
$$

여기서 $\mathrm{E}, \hbar, \mathrm{k}, \mathrm{m}_{\mathrm{e}}^{*}$ 는 각각 전자의 운동 에너지, 플랑 크 상수, 전자의 운동량 및 전자의 유효 질량을 나타낸 다. 복합 재료 내에 있는 전체 전자 중 계면의 에너지 장 벽을 뚫고 전달될 수있는 전자의 분율은, 결국 계면에
있는 에너지 장벽을 “뚫을 수 있느냐”의 여부가 중요하 다. 이는 계면을 뜷는 방향인 $\mathrm{z}$ 방향의 운동량 $\left(\mathrm{k}_{\mathrm{z}}\right)$ 으로 인한 운동 에너지가 계면에서의 에너지 장벽보다 커야 함을 의미한다 $\left(\frac{\hbar^{2} \mathrm{k}_{\mathrm{z}}^{2}}{2 \mathrm{~m}_{\mathrm{e}}^{*}}>\mathrm{E}_{\mathrm{b}}\right)$. 이에 대응하는 전자의 분율 은, 운동량 보존을 가정할 때와 가정하지 않을 때, Fig 6 (c)의 $\mathrm{V}_{1}$ 및 $\mathrm{V}_{2}$ 로 각각 표현될 수 있다.

계면 장벽 에너지에 의한 전자의 선택적 산란 때문에, 기존 “자유 전자" 중 장벽을 극복할 수 없는 분율은 더 이상 자유 전자가 아니게 되어버린다. 즉, 전도에 활용 


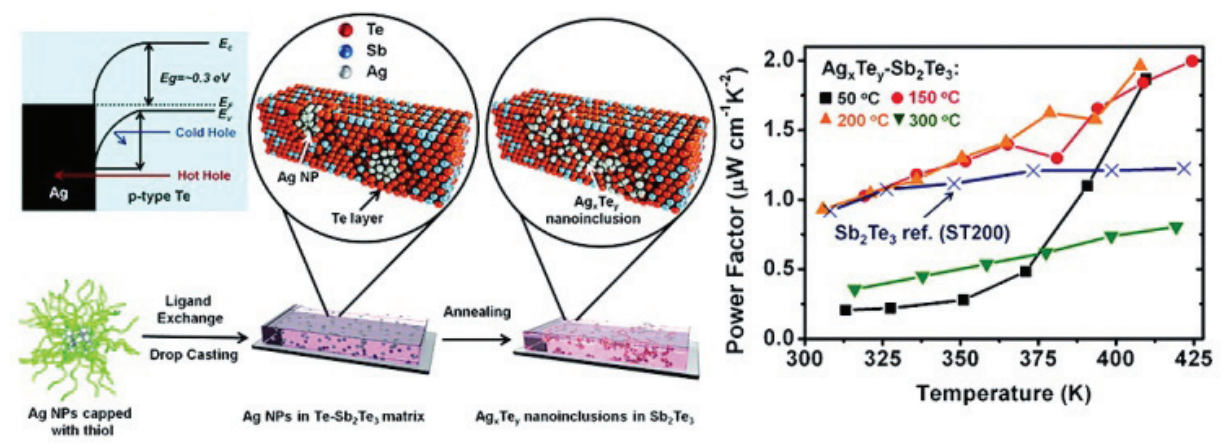

Fig 7. $\mathrm{Ag}$ 나노 입자를 포함하는 $\mathrm{p}$ 형 $\mathrm{Sb}_{2} \mathrm{Te}_{3}$ 매트릭스의 계면에서 쇼트키 장벽이 생겨나고, 이는 에너지 의존 전하 캐리어 산란을 일으킨다. 낮은 운동 에너지를 가진 전하 캐리어만이 선택적으로 산란되고, 이는 제벡 계수의 변화를 유도하여 출력인자을 증가시킨다. Figure from Silver-based intermetallic heterostructures in $\mathrm{Sb}_{2} \mathrm{Te}_{3}$ thick films with enhanced thermoelectric power factors and used with permission from the American Chemical Society"1.

되는 "자유" 전자의 농도가 감소되고, 따라서 전체 전기 전도도가 감소한다 (수식 4). Fig 6 (d)는 계면 장벽 에 너지가 없는 상황과 있는 상황에서의 전자 에너지 별 전 도도 (differential conductivity, $\sigma(\mathrm{E})$ 를 통계적 분포로 나타낸 그림으로, 이 그림을 통해 계면 장벽 에너지에 의한 산란이 제벡 계수에 어떤 효과를 일으키는지 유도 할 수 있다. $\sigma(\mathrm{E})$ 는 특정 에너지 $\mathrm{E}$ 를 가진 전자의 농도 와 이동도의 곱으로써, 이 함수를 전체 전자 에너지 범 위에서 적분하면 거시적으로 측정되는 재료의 전기 전 도도를 구할 수 있다. Fig 6 (d)에서 나타나듯이, 전하 캐리어 산란 메커니즘이 적용되면 장벽 에너지보다 낮 은 에너지를 가진 전자는 국소화된다 (localized). 국소 화된 전자들 역시 전하 캐리어 농도를 가지나 $(n \neq 0)$, 이동도는 0 이기 때문에 $(\mu=0)$, 이 두 항의 곱인 $\sigma(\mathrm{E})$ 함 수는 0이 된다 (수식 4). 따라서 인 전자들에 의한 차동 전도도는 0이 되어 $\left(\mathrm{E}<\mathrm{E}_{\mathrm{b}}\right)$, Fig 6 (d)의 오른쪽에 표시 된 것처럼 비대칭적인 $\sigma(\mathrm{E})$ 를 보인다. 여기서 페르미 레 벨이 변하지 않는다는 점이 중요한데, 이는 에너지 장벽 이 전자를 움직이지 못하게만 만든 것이지, 전자 그 자 체를 제거한 것이 아니기 때문이다.

$\sigma(\mathrm{E})$ 는 모트 공식 (Mott formula)을 통해 제벡 계수 와 연관될 수 있다 ${ }^{17}$.

$$
\mathrm{S}=\left.\frac{\pi^{2} \mathrm{k}_{\mathrm{B}}^{2} \mathrm{~T}}{3 \mathrm{e}} \frac{\partial \ln \sigma(\mathrm{E})}{\partial \mathrm{E}}\right|_{\mathrm{E}=\mathrm{E}_{\mathrm{F}}}
$$

수식 8에 의하면, 열전 재료의 제벡 계수는 페르미 레 벨에서 $\ln (\sigma(\mathrm{E}))$ 함수의 에너지에 대한 기울기에 비례하 며, 여기서 $\mathrm{k}_{\mathrm{B}}, \mathrm{T}$ 및 $\mathrm{e}$ 는 볼츠만 상수, 절대 온도 및 기 본 전하를 나타낸다. $\ln (\sigma(\mathrm{E}))$ 기울기는 계면 장벽 에너 지에 의한 전자의 선택적 산란이 있는 상황에서 훨씬 크 고, 이는 제벡 계수 역시 커짐을 의미한다. 즉, 계면 에 너지 장벽에 의한 전하 캐리어 산란 메커니즘으로 인 해 전기 전도성은 저하되지만 그 댓가로 제벡 계수는 향 상시킬 수 있음이 증명된다. 또한, 전기 전도성을 얼마 나 많이 희생하고, 제벡 계수를 얼마나 높일 수 있는지 는 재료의 선택으로 어느 정도 조절 가능하다는 결론도 얻을 수 있다. 즉, 장벽의 높이는 복합 열전 소재에 어떤 재료가 들어가서 이루는 계면에서의 밴드 에너지 불연 속이기 때문에, 예측과 설계가 가능하고, 이것으로 출력 인자을 최적화하는 또 다른 가능성이 생긴다.

Fig 6 (e)은 증가된 제벡 계수가 감소한 전기 전도도 에도 불구하고 결국 ZT의 향상으로 이어질 수 있음을 예측한다. 이 메커니즘은 반드시 전기 전도도의 감소를 불러오기 때문에, 높은 전기 전도성를 이미 지녔으되 낮 은 제벡 계수 때문에 출력인자이 작은 재료에만 적합하 다. 이 특성은 금속의 특성과 잘 일치하며, 이것이 특히 금속 기반의 복합 재료에서 이 출력인자 향상 메커니즘 
에 대한 논의가 시작된 이유이다 ${ }^{13}$. 이에 반해, 변조 도 핑 메커니즘은 제벡 계수를 떨어뜨리지 않고 전기 전도 도를 증가시킨다는 점에서, 도핑되지 않은 반도체 소재 에서 더 적합하다는 대조를 할 수 있다.

Fig 6 (e)에 언급된 매우 큰 ZT는 계면에서의 음향 양자의 이동, 즉 열 전도가 방해받기 때문에 일어날 수 있다. 이전에 언급했듯이, 음향양자의 평균 자유 경로 는 일반적으로 전하 캐리어의 평균 자유 경로보다 훨씬 더 크다. Fig 6 (e)에서는 $5 \mathrm{~nm}-20 \mathrm{~nm}$ 주기의 계면 을 가진 초격자 (superlattice)가 가정되었으므로, 음향 양자는 전자 이상으로 더 많이 산란될 것이다. 음향양자 의 빈번한 산란은 열 전도도를 $\sim 1 \mathrm{~W} / \mathrm{m} \cdot \mathrm{K}$ 에 이를 때 까지 크게 억제할 것으로 추산되었고, 이는 벌크 금속의 열 전도도보다 수백배 가량 작은 것이다.

복합 재료 내 계면에서의 에너지 장벽을 통한 전하 캐 리어 산란은 실제로 출력인자 증강을 이끌어 낼 수 있 음이 실제 실험으로도 증명되었다 (Fig 7). 해당 재료는 $\mathrm{Ag}$ 나노 입자를 포함하는 $\mathrm{Sb}_{2} \mathrm{Te}_{3}$ 매트릭스라는 복합 재 료이다. 여기서 $\mathrm{p}$ 형 $\mathrm{Sb}_{2} \mathrm{Te}_{3}$ 매트릭스는 이미 최첨단 열 전 소재로, 전기 전도도가 $\sim 70 \mathrm{~S} / \mathrm{cm}$ 로 보통의 금속보 다는 낮고, 통상적인 반도체보다는 높은 전기 전도도를 가지고 있다. 이 연구의 핵심은 $\mathrm{Ag}$ 나노 입자와 $\mathrm{Sb}_{2} \mathrm{Te}_{3}$ 사이 계면에서 출력인자 증강을 위해 적절한 높이의 에 너지 장벽이 생기도록 한 재료의 선택에 있다. 이제까 지 설명된 계면 장벽 에너지에 의한 전자 산란 메커니즘 에 따르면, 금속인 $\mathrm{Ag}$ 나노 입자가 전자를 통과시키지 않고 산란시키는 재료로 쓰인다는 점이 놀라울 수 있다. 여기서의 $\mathrm{Ag}$ 나노 입자는 $\mathrm{p}$ 형 $\mathrm{Sb}_{2} \mathrm{Te}_{3}$ 에서 쇼트키 장벽 (Schottky barrier)을 형성하기 때문에, $\mathrm{p}$ 형 $\mathrm{Sb}_{2} \mathrm{Te}_{3}$ 를 통 해 이동하는 정공을 방해할 수 있다. 또한, 이 경우에서 $\mathrm{Ag}$ 나노 입자는 서로 충분한 공간을 두고 분리되어 있어 서, $\mathrm{Ag}$ 나노 입자'만'을 통한 정공의 전도는 불가능하다.

쇼트키 장벽을 만든 $\mathrm{Ag}$ 나노 입자 때문에 $\sigma(\mathrm{E})$ 는 페 르미 레벨 인근에서 아주 큰 기울기를 가지게 된다 (Fig 6 (d)). 이로 인해 제벡 계수는 확대되고 (수식 8), 출력 인자도 향상된다 (Fig 7). 또한 $\mathrm{Sb}_{2} \mathrm{Te}_{3}$ 를 통해 전도되던 음향양자가 $\mathrm{Ag}$ 나노 입자와의 계면에서 자주 산란되었
기 때문에 열 전도도의 감소 효과도 발생하였다 ${ }^{10,11}$. 이 는 출력인자의 증강 이외에도 $\mathrm{ZT}$ 가 추가적으로 상승할 수 있는 요인을 제공한다.

\section{결론}

본 논문에서는 복합 열전 재료에서의 출력인자 증 강 메커니즘인 전하 캐리어 산란 (energy-dependent charge carrier scattering)과 변조 도핑 (modulation doping)에 대해 살펴보았다. 근본적으로는 2가지 메 커니즘 모두 출력인자의 향상을 통해 ZT의 증대를 도 모하는 전략이다. 또한 복합 재료를 취하면 음향양자 (phonon)의 산란이 보장되면서 열 전도도가 억제되고, 이 효과에 의해서도 ZT의 상승이 일어나기도 한다. 변 조 도핑은 제벡 계수의 하향 없이 전기 전도도의 상승 을 도모하여 출력인자을 늘이려는 전략이다. 전기 전도 도는 전하 캐리어의 농도와 전하 이동도의 곱에 비례하 는데, 총 전하 캐리어의 갯수를 그대로 보존한채로 전 하 이동도가 높은 재료에서 대부분의 전하 캐리어가 전 도되도록 유도하는 것이 핵심이다. 이에 반해, 전하 캐 리어 산란 메커니즘은 전하 캐리어의 이동도와 전기 전 도도를 일부 희생하여, 제벡 계수를 키우는 전략이다. 첫 번째 단계는 복합 재료 중 한 가지 재료로 전하 캐 리어들 중 에너지가 작은 것들이 통행할 수 없는 에너 지 장벽을 설치하여, 그들의 이동도를 떨어뜨리는 것 이다. 이로 인해, 전하 캐리어가 가진 에너지별 전도도 (differential conductivity)가 바뀌어 제벡 계수가 상승 한다. 열역학적인 관점에서는, 캐리어 1 개가 수송하는 평균 에너지의 크기를 키움으로써, 제벡 계수를 올리는 방식이라고 기술할 수 있다.

\section{ACKNOWLEDGEMENT}

This work was supported by the National Research Foundation of Korea (NRF) grant funded by the Korea government (MSIT) (No. 2021R1G1A1008987). This work was also supported by 2020 Hongik University Research Fund. 


\section{REFERENCES}

1. Ling-Chin, J.; Bao, H.; Ma, Z.; Taylor, W.; Roskilly, A. P., State-of-the-art technologies on low-grade heat recovery and utilization in industry. In Energy conversion : current technologies and future trends., Al-Bahadly, I. H., Ed. IntechOpen: 2018; pp 55-74.

2. Rowe, D. M., CRC handbook of thermoelectrics. Boca Raton, FL : CRC Press, c1995.: 1995.

3. Kunets, V. P.; Teodoro, M. D.; Dorogan, V. G.; Lytvyn, P. M.; Tarasov, G. G.; Sleezer, R.; Ware, M. E.; Mazur, Y. I.; Krasinski, J. S.; Salamo, G. J., Interface roughness scattering in laterally coupled InGaAs quantum wires. Applied Physics Letters 2010, 97, 262103.

4. Dresselhaus, M. S.; Chen, G.; Tang, M. Y.; Yang, R. G.; Lee, H.; Wang, D. Z.; Ren, Z. F.; Fleurial, J. P.; Gogna, P., New directions for low-dimensional thermoelectric materials. Advanced Materials 2007, 19, 1043-1053.

5. Zebarjadi, M.; Esfarjani, K.; Dresselhaus, M. S.; Ren, Z. F.; Chen, G., Perspectives on thermoelectrics: from fundamentals to device applications. Energy Environ. Sci. 2012, 5, 5147-5162.

6. Yu, B.; Zebarjadi, M.; Wang, H.; Lukas, K.; Wang, H.; Wang, D.; Opeil, C.; Dresselhaus, M.; Chen, G.; Ren, Z., Enhancement of thermoelectric properties by modulation-doping in silicon germanium alloy nanocomposites. Nano letters 2012, 12, 2077-82.

7. Zebarjadi, M.; Joshi, G.; Zhu, G.; Yu, B.; Minnich, A.; Lan, Y.; Wang, X.; Dresselhaus, M.; Ren, Z.; Chen, G., Power factor enhancement by modulation doping in bulk nanocomposites. Nano letters 2011, 11, 2225-30.

8. Yucheng, L.; Jerome, M. A.; Gang, C.; Zhifeng, R., Enhancement of Thermoelectric Figure of Merit by a Bulk Nanostructuring Approach. Advanced Functional Materials 2010, 20, 357-376.

9. Minnich, A. J.; Dresselhaus, M. S.; Ren, Z. F.; Chen, G., Bulk nanostructured thermoelectric materials: current research and future prospects. Energy \& Environmental Science 2009, 2, 466-479.

10. Zhang, Y.; Bahk, J. H.; Lee, J.; Birkel, C. S.; Snedaker, M. L.; Liu, D.; Zeng, H.; Moskovits, M.; Shakouri, A.; Stucky, G. D., Hot carrier filtering in solution processed heterostructures: a paradigm for improving thermoelectric efficiency. Adv Mater 2014, 26, 275561, 2618.

11. Zhang, Y.; Snedaker, M. L.; Birkel, C. S.; Mubeen, S.;
Ji, X.; Shi, Y.; Liu, D.; Liu, X.; Moskovits, M.; Stucky, G. D., Silver-based intermetallic heterostructures in $\mathrm{Sb}_{2} \mathrm{Te}_{3}$ thick films with enhanced thermoelectric power factors. Nano letters 2012, 12, 1075-80.

12. Kim, W.; Singer, S. L.; Majumdar, A.; Vashaee, D.; Bian, Z.; Shakouri, A.; Zeng, G.; Bowers, J. E.; Zide, J. M. O.; Gossard, A. C., Cross-plane lattice and electronic thermal conductivities of ErAs:InGaAs/nGaAlAs superlattices. Applied Physics Letters 2006, 88, 242107.

13. Vashaee, D.; Shakouri, A., Improved thermoelectric power factor in metal-based superlattices. Physical review letters 2004, 92, 106103.

14. Dingle, R.; Störmer, H. L.; Gossard, A. C.; Wiegmann, W., Electron mobilities in modulation doped semiconductor heterojunction superlattices. Applied Physics Letters 1978, 33, 665-667.

15. Lee, D.; Sayed, S. Y.; Lee, S.; Kuryak, C. A.; Zhou, J.; Chen, G.; Shao-Horn, Y., Quantitative analyses of enhanced thermoelectric properties of modulationdoped PEDOT:PSS/undoped Si (001) nanoscale heterostructures. Nanoscale 2016, 8, 19754-19760.

16. Zebarjadi, M.; Esfarjani, K.; Bian, Z.; Shakouri, A., Low-Temperature Thermoelectric Power Factor Enhancement by Controlling Nanoparticle Size Distribution. Nano letters 2011, 11, 225-230.

17. Cutler, M.; Mott, N. F., Observation of Anderson Localization in an Electron Gas. Physical Review 1969, 181, 1336-1340.

18. Lee, K. H.; Kim, S. W., Design and Preparation of High-Performance Bulk Thermoelectric Materials with Defect Structures. J Korean Ceram Soc 2017, 54, 75-85.

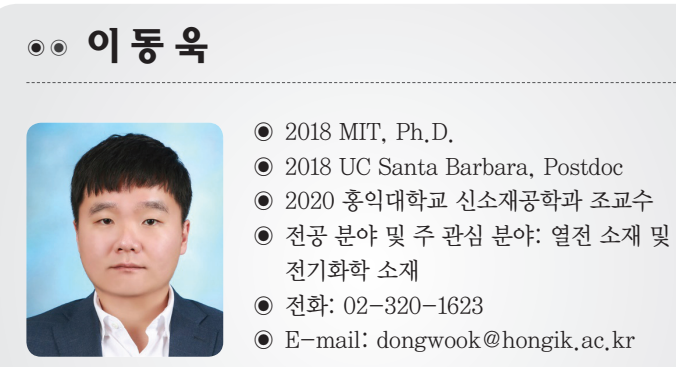

